\title{
THE THEORY OF PLANNED BEHAVIOR TOWARD ORGANIC FOOD IN VIETNAM: THE MODERATION OF ENVIRONMENTAL CONCERN
}

\author{
Hung Cuong Hoang, Miloslava Chovancová, Hoang Thi Que Huong, \\ Abdul Bashiru Jibril
}

\begin{abstract}
With the increases in environmental concern, customers are more and more pay attention to purchase organic food. Despite purchase intention of customers toward organic food in many nations being commonly studied, there is a lack of research related to the moderation of environmental concern based on the Theory of Planned Behaviour (TPB). In this research, this study investigates the moderation of environmental concerns based on the theory of planned behaviour toward organic food in Vietnam. The methodology of mixed-methods of qualitative and quantitative is applied with a survey of 420 customers being conducted to collect data from three biggest cities in Vietnam: Ho Chi Minh, Da Nang and Ha Noi. The result shows that the customers have more environmental concern which increases their attitude to intention of purchasing organic food. This enriches the existing literature with the moderation of environmental concern to the relationship of attitude and purchase intention toward organic food in Vietnam based on the Theory of Planned Behaviour.
\end{abstract}

Keywords: environmental concern, theory of planned behaviour, organic food, moderation, purchase intention

\section{INTRODUCTION}

In recent decades the environmental concern (EC) has gradually increased (Han, Hsu, \& Sheu, 2010). The ongoing and increasing overuse and depletion of natural resources like soil, land, and water is a major threat to human biodiversity. Consumers are aware of environmental issues in relation to their use, they are trying to buy products that are environmentally friendly (Paul, Modi, \& Patel, 2016). Increased numbers of customers with various environmental problems start looking for and purchasing environmentally friendly products via alternatives, sometimes paying even more for these products (Laroche, Bergeron, \& Barbaro-Forleo, 2001). In line with this trend, consumers' demand for green establishments has steadily increased in the lodging industry. Most consumers are aware of the damage to the community for the good of future generations. Although personal satisfaction remains central to consumer behaviour, preservation of the environment is also a key concern (Paul et al., 2016; Verbeke et al., 2007)

Empirical evidence is growing that environmental work focused on Theory of Planned Behaviour (TPB) is based on many dimensions, including tourism management (Han et al., 2010; Leelapattana et al., 2019; Wang et al., 2018), energy and waste (Li et al., 2019; Shen et al., 2019), green product consumption (Maichum, Parichatnon, \& Peng, 2016; Paul et al., 2016; Yadav \& Pathak, 2016). So far, scholars have published papers related to intention purchasing towards organic food. To have better understanding the purchasing intention used theory of planned behaviour, some studies have been investigated (Michaelidou \& Hassan, 2008; Peighambari et al., 2016; Bonti-ankomah \& Yiridoe, 2006) as well as empirical studies regarding factors influencing purchasing intention of organic food (Shaharudin et al., 2010; Singh \& Verma, 2018); willingness to pay organic food (Aryal et al., 2009; Krystallis \& Chryssohoidis, 2005; Zhang et al., 2018). 
In the scope of expected Theory of Planned Behaviour (TPB) towards the purchasing of organic food, many researchers pay attention to the indirect and direct relationship between environmental concern (Chekima, Chekima, \& Chekima, 2019; Pham et al., 2018; Yiridoe et al., 2014), but lacking of research related to how environmental concern impacts the relationship of personal attitude to purchase intention toward organic food. This study attempts to answer the following key research questions: the first question is whether the increase in environmental concern will increase the relationship of attitude to purchase intention toward organic food? The second is how is the influencing of factors in theory of planned behaviour to purchase intention? Therefore, research objectives of this study are: 1) to test the moderation of environmental concern in the Theory of Planned Behaviour (TPB) toward organic food in Vietnam, 2) to evaluate the relationship of personal attitude, subjective norms, and perceived behavioural control to purchase intention toward organic food in Vietnam.

The strength of this study to theory contribution is to update the moderation relationship of environmental concern based on theory of planned behaviour. In the practical fields, companies understand the importance of environmental concern of their customers. With launching many environmental activities, companies which producing organics food will increase the environmental concern of customers. It leads the raise in organic purchasing intention. The environment of the world and the health of human being would be better when using organic food. In the following section, Theory of Reasoned Action (TRA), TPB, and the conceptual framework that supports the research hypotheses are described. In the methodology section, measurement development, data collection and analysing are illustrated. Finally, study findings, implications, and conclusion are discussed in the results and conclusion sections.

\section{LITERATURE REVIEW}

\subsection{Theory background}

The theory of planned behaviour (TPB) is a cognitive model that targets to predict the intention and behaviour (Ajzen, 1991). This model has been widely used in various areas, such as health psychology (Walker, Grimshaw, \& Armstrong, 2001; Zemore \& Ajzen, 2014), environmental behaviour (Abrahamse \& Steg, 2009), diet and food choice intention and actual behaviour (Arvola et al., 2008; Kim et al., 2013), green consumption (Al et al., 2018), intention of tourists and green hotel choices (Han et al., 2010; Wang et al., 2018).

From the Theory of Reasoned Action (TRA), The Theory of Planned Behaviour was developed (Fishbein \& Ajzen, 1977). This model is a social psychological model describing behavioural intentions and actual behaviour based on attitude and subjective norm (Fishbein \& Ajzen, 1977). For many factors, there are differences between actual behaviour and behavioural intention; in 1985, when the Theory of Planned Behaviour was written, Ajzen presented a further factor. The mediate variable is called "perceived behavioural control (PBC), which directly influences intention and behaviour.

In the Theory of Planned Behaviour, the first component of the model is intended to find out a "personal attitude" to the behaviour by determination of beliefs outcome and evaluation outcome. The outcome beliefs are related to what we believe to be the outcome of taking their behaviour and the outcome evaluation mentions how worthwhile we consider the outcome of the behaviour (Ajzen, 1991). The second part of the model aims to find out a person's "subjective norms" which is made of their normative beliefs and motivation to comply. The third part of the model looks at our personal control beliefs, which are made up of self- efficacy beliefs and perceived external barriers. The self- efficacy beliefs are about how confident we are we can achieve the change even in the face of barriers and the perceived external barriers 
describe external factors that we perceive might prevent to achieve goals (Ajzen, 1991). Therefore, according to the Theory of Planned Behaviour (TPB), customers who have positive attitudes in regard to organic food, have normative support for using it, feel easy and comfortable to use this food, have strong intention to purchase this organic food.

\subsection{Hypothesis development}

In the Theory of Planned Behaviour, attitude refers to negative or positive evaluation related to behaviour investigation. There is an assumption that the more positive the attitude, the more possibly the intention (Nosi et al., 2017). Moreover, the more support of normative factor is, the more positive affect to purchase intention is. The normative support can be from parents, friends, or someone who has influences to. Besides, if customer feel comfortable to purchase organic food and it is easy for them to approach the purchasing this food, the relationship between perceived behavioural control and purchase intention is positive. There are many researches that prove the positive relationship between attitude of customer, subject norm, perceived behavioural control and purchase intention toward organic food (Arvola et al., 2008; Chen, 2007; Singh \& Verma, 2018; Tsakiridou et al., 2008; Yazdanpanah \& Forouzani, 2015). Thus, we posit that:

\section{H1: Attitude toward organic food will be positively related to purchase intention}

\section{H2: Subject norm toward organic positively affects purchase intention}

\section{H3: Perceived behaviour control positively affects purchase intention}

In this article, they argue that the relationship between attitude and purchase intention may depend on a number of boundary conditions that may alter the strength of this relationship. One constraint could be the extent or degree of environmental concern that may vary the strength of this relation. Firstly, according to Hu et al. (2010), environmental concerns is identified as "to the extent to which people are aware of environmental issues and endorse efforts to resolve them or to show their personal readiness to contribute to their solution" (Paul et al., 2016). Furthermore, researchers describe environmental concerns as being aware of environmental issues and their ability to tackle environmental challenges (Maichum et al., 2016). There are many researches proved the positive effect of environmental concern to purchase intention based on the theory of planned behaviour. For example, the study pointed out that the effect of ecological concerns and consumer purchase intentions for organic food (Pomsanam, Napompech, \& Suwanmaneepong, 2014; Ragavan \& Mageh, 2012); for the eco-friendly products and services (Aman, Harun, \& Hussein, 2012; Han, Hsu, \& Lee, 2009; Hartmann \& Apaolaza-Ibáñez, 2012). Sang and Bekhet (2015) reported a significant positive impact of environmental concern on consumer intention to buy an electric vehicle (Yadav \& Pathak, 2016). Mostafa (2009) identified environmental concern among the major variables which influences consumers' attitude as well as their intention to buy green products. Mostafa (2007) also reported that environmental concern positively influences the consumers' attitude towards green products which further influences their green purchase intention.

However, Diamantopoulos et al. (2003) observed that environmental concerns are a significant consumer decision-making variable. Aman et al. (2012) noted that the incentive to purchase green products would be enhanced by an increasing number of consumers with environmental concern. Additional studies also show that environmental issues not only impact the behavioural will but also influence behavioural attitudes; consumers with greater environmental concern tend to adopt a more positive environmental attitude, which in turn increases their willingness to act (Chen \& Peng, 2012; Clark, Kotchen, \& Moore, 2003; Kalafatis et al., 1999). From the above arguments, the following hypothesis can be stated that: 
H4: The positive relationship between attitude and purchase intention will be stronger when environmental concern is high.

Based on the above discussion a theoretical model can be developed:

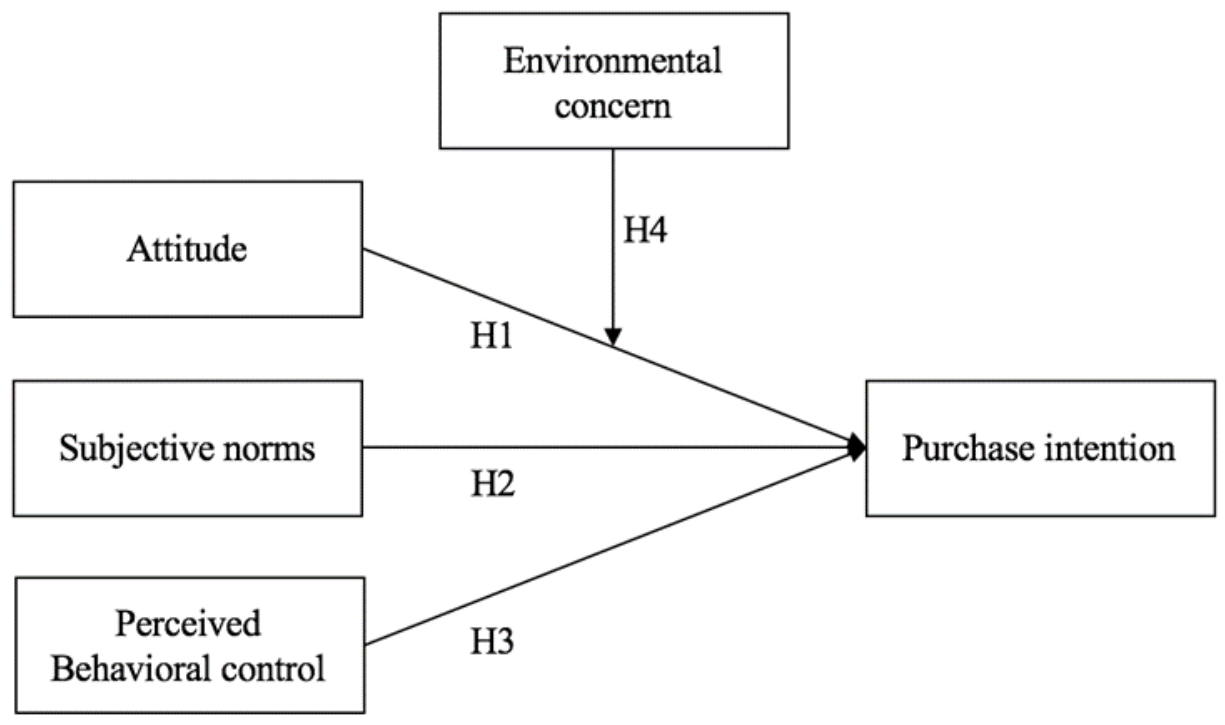

Fig. 1 - The proposed research framework. Source: own research

\section{METHODOLOGY}

\subsection{Research design}

The study is applicable to both investigation approaches, including inductive and deductive methods. First, the inductive approach is used. This method seeks to gain a better understanding of organic purchasing and environmental concern. According to Saunders, Lewis, \& Thornhill (2009), the strength of the inductive approach is to develop an understanding of the nature of the problem.

This study applied mixed-methods to investigate. According to Creswell (2014), one of the best ways to have a clear understanding of research problem is using mixed-methods. The mixedmethods is to corporate the qualitative and quantitative data collection and analysis procedures which are employed either simultaneously or sequentially in a single study (Pham, Tučková, \& Chiappetta Jabbour, 2019)

\section{Qualitative research}

Qualitative research is often defined as a study which aims at creating models instead of testing hypotheses (Bryman \& Bell, 2011). Saunders et al. (2009) have mentioned that qualitative research is interpretive since scientists should recognize the significance of the chosen event or theme. Similar approaches are included in a qualitative process, for example: comprehensive interviews with people, action research reflection and team focal interviews. The purpose of the qualitative approach is to have a deep knowledge of a scenario or problem. This research focuses on the qualitative methodology with 10 Vietnamese customers, to identify and gain more understanding on planned behaviour theory and environment variable constructs

\section{Quantitative research}

Research objectives of this study aim to explore the effect of environmental concern on theory of planned behaviour toward organic food in Vietnam. Thus, the quantitative method is required 
to achieve these objectives. The research strategy used in this study is survey. The survey research is to apply quantitative data collection, and is applied to measure the relationship between variables and propose the model (Saunders et al., 2009).

\subsection{Data collection}

\section{Object of analysis}

The ideal sample of this research is adults (18 years of age or older). More capacity for comparing and evaluating available options is related to adults. In addition, highly educated customer can give better understanding the topic with discussion and accreted providing of information as opposed to less well-educated people. (Han et al., 2010; Han \& Kim, 2010; Hedlund, 2011). Hence, the data collection will be collected from consumers who have high education of above high school qualification.

\section{Qualitative study}

For the qualitative study, the focus group is conducted to collection data. The semi-structured interview is suitable for this stage. The objects of this interview are 10 customers who their age is 18 or over. The customers can be purchased organic food in the past or never purchase organic food.

\section{Quantitative study}

First of all, the questionnaire is developed with for five constructs: attitude, subjective norms, perceived behavioural control, purchase intention, and environmental concern. The study used measurement scales established in previous studies. The type scale applied for the measurement uses Likert of 5-point. Originally, questionnaire was written in English. The first author and a further bilingual scholar worked on this initial questionnaire in Vietnamese before it was translated into English. The data is collected by online using google form of questionnaire and offline by meeting directly customers. Three biggest cities in Vietnam chosen for this study are Ho Chi Minh City, Da Nang City, and Hanoi City. At the first stage, pilot study is conducted with sample of 70-100 customers. The purpose of this stage is to get more understanding of customer preparing for full study at the second stage. Another target is to estimate effect size for the full study. At the second stage, the full study is implemented with sample size which based on effect size of the pilot study. Moreover, the sample size sufficient for this research was calculated based upon the recommendation of Hair et al., (2013) for a desired level of 15 to 20 observations per variable examined. Our study consists of five constructs $(6$ items for attitude, 4 items for subjective norm items, 2 items for PBC, 6 environmental concern items and 4 purchase intention items, total of 22 items) resulting in an optimal sample size of 420 respondents. Table 1 illustrates the measurement scales for all constructs.

Tab. 1 - Measures description and properties. Source: own research

\begin{tabular}{|c|c|c|}
\hline Measures & Item description & Fact. Load \\
\hline \multirow{6}{*}{$\begin{array}{l}\text { Attitude (ATT) } \\
\text { (Ajzen, 2002; Arvola } \\
\text { et al., 2008) }\end{array}$} & $\mathrm{X} 1$ : I think that purchasing organic food is interesting & 0.724 \\
\hline & X2: I think that purchasing organic food is a good idea & 0.807 \\
\hline & $\mathrm{X} 3$ : I think that purchasing organic food is important & 0.770 \\
\hline & X4: I think that purchasing organic food is beneficial & 0.855 \\
\hline & $\mathrm{X} 5$ : I think that purchasing organic food is wise & 0.875 \\
\hline & X6: I think that purchasing organic food is favorable. & 0.775 \\
\hline \multirow{3}{*}{$\begin{array}{l}\text { Subjective Norms } \\
\text { (SBN) } \\
\text { (Ajzen, 2002; Arvola } \\
\text { et al., 2008) }\end{array}$} & $\begin{array}{l}\text { X7: My family thinks that I should buy organic food rather than non- } \\
\text { organic food }\end{array}$ & 0.724 \\
\hline & $\begin{array}{l}\text { X8: Most people I value would buy organic food rather than non- } \\
\text { organic food }\end{array}$ & 0.881 \\
\hline & $\begin{array}{l}\text { X9: People I value (such as my teacher) think you should buy organic } \\
\text { food }\end{array}$ & 0.871 \\
\hline
\end{tabular}




\begin{tabular}{|c|c|c|}
\hline & $\begin{array}{l}\text { X10: My close friends, whose opinions regarding diet are important to } \\
\text { me, think that I should buy organic food }\end{array}$ & 0.753 \\
\hline \multirow{2}{*}{$\begin{array}{l}\text { Perceived Behavioral } \\
\text { Control (PBC) } \\
\text { (Ajzen, 2002; Arvola } \\
\text { et al., 2008) }\end{array}$} & $\begin{array}{l}\text { X11: If I wanted to, I could buy organic food instead of non- organic } \\
\text { food }\end{array}$ & 0.772 \\
\hline & X12: I think it is easy for me to buy organic food & 0,721 \\
\hline \multirow{6}{*}{$\begin{array}{l}\text { Environmental } \\
\text { Concern (EC) } \\
\text { (Kilbourne \& Pickett, } \\
\text { 2008; Maichum et al., } \\
\text { 2016; Paul et al., } \\
\text { 2016) }\end{array}$} & X13: I am very concerned about the environment & 0.862 \\
\hline & X14: Humans are severely abusing the environment & 0.840 \\
\hline & $\begin{array}{l}\text { IX15: I would be willing to reduce my consumption to help protect } \\
\text { the environment }\end{array}$ & 0.661 \\
\hline & $\begin{array}{l}\text { X16: Major political change is necessary to protect the natural } \\
\text { environment }\end{array}$ & 0.519 \\
\hline & $\begin{array}{l}\text { X17: Major social changes are necessary to protect the natural } \\
\text { environment }\end{array}$ & 0.650 \\
\hline & X18: Anti-pollution laws should be enforced more strongly & 0.856 \\
\hline \multirow{4}{*}{$\begin{array}{l}\text { Purchase Intention } \\
\text { (PI) } \\
\text { (Ajzen, 2002; Arvola } \\
\text { et al., 2008) }\end{array}$} & $\begin{array}{l}\text { X19: I am willing to consume organic food if they are available for } \\
\text { purchase }\end{array}$ & 0.840 \\
\hline & $\begin{array}{l}\text { X20: I intend to consume organic food if they are available for } \\
\text { purchase }\end{array}$ & 0.911 \\
\hline & X21: I plan to consume organic food if they are available for purchase & 0.859 \\
\hline & $\begin{array}{l}\text { X22: I will try to consume organic food if they are available for } \\
\text { purchase }\end{array}$ & 0.782 \\
\hline
\end{tabular}

\subsection{Data analysis}

\section{Quantitative study}

In respect to data analysis, the accuracy and quality of the measurement device was evaluated first. Then, regression was used to analyse the effect on TPB of environmental concerns. The PROCESS model was primarily used for clarifying interactive factors. The PROCESS model for SPSS programs were developed and implemented (Hayes \& Rockwood, 2017). This process makes it easier to estimate regression equations because of its convenience and ease of use (Hayes \& Rockwood, 2017). Moreover, SMART- PLS is applied to analyse the relationship between variable as well as to calculate the reliability and validity.

\section{RESULTS}

The sample characteristics analysis of the study is illustrated in the Table 2 .

Tab. 2 - Sample characteristics. Source: own research

\begin{tabular}{|c|l|r|r|}
\hline Variable & \multicolumn{1}{|c|}{ Categories } & Frequency & Percentage \\
\hline \multirow{4}{*}{ Gender } & Male & 192 & $46 \%$ \\
\cline { 2 - 4 } & Female & 228 & $54 \%$ \\
\hline \multirow{4}{*}{ Age } & Less than 20 years & 37 & $9 \%$ \\
\cline { 2 - 4 } & $20-35$ years & 196 & $47 \%$ \\
\cline { 2 - 4 } & $36-50$ years & 159 & $38 \%$ \\
\cline { 2 - 4 } & More than 50 years & 28 & $7 \%$ \\
\hline \multirow{4}{*}{ Marital Status } & Single & 245 & $58 \%$ \\
\cline { 2 - 4 } & Married & 170 & $40 \%$ \\
\cline { 2 - 4 } & Divorced/Widow & 5 & $1 \%$ \\
\hline \multirow{5}{*}{ Family size } & 1 person & 42 & $10 \%$ \\
\cline { 2 - 4 } & $2-3$ persons & 153 & $36 \%$ \\
\cline { 2 - 4 } & $4-5$ persons & 185 & $44 \%$ \\
\cline { 2 - 4 } & More than 5 persons & 40 & $10 \%$ \\
\hline \multirow{3}{*}{ Employment status } & Full-time job & 184 & $44 \%$ \\
\cline { 2 - 4 } & Part-time job & 52 & $12 \%$ \\
\cline { 2 - 4 } & Student & 69 & $16 \%$ \\
\hline
\end{tabular}




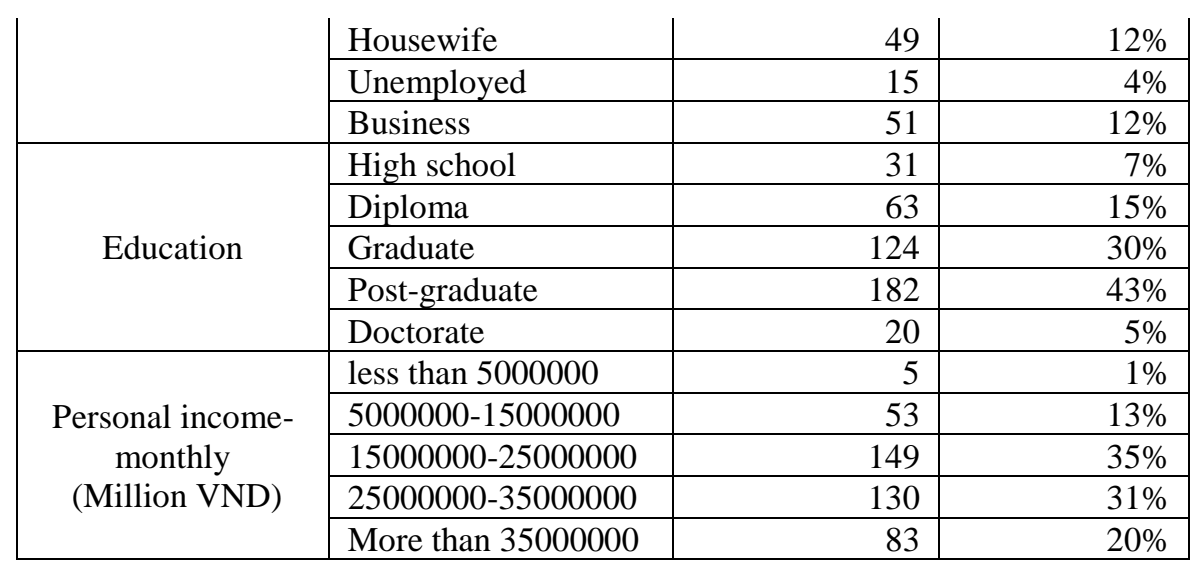

Hair et al. (2013) suggests that Cronbach's Alpha should be 0.7 or higher with an appropriate loading of 0.5 or higher for such measurements. Furthermore, the proportion of variance explained must exceed 50 percent. Table 3 shows that this finding meets the measurement reliability and validity criteria. Average Variance Extracted values (AVE) are higher than 0.5. Moreover, we used the approach used by (Fornell \& Larcker, 1981) to assess discrimination by comparing square of AVE with square correlations between constructs. In Table 4, the square of AVE exceeds the squared correlations indicating discriminant validity (Paul et al., 2016).

Tab. 3 - Expected Reliability of scales. Source: own research

\begin{tabular}{|c|c|c|c|c|c|}
\hline Variable & Item & $\begin{array}{c}\text { Corrected Item-to- } \\
\text { total correlation }\end{array}$ & $\begin{array}{c}\text { Cronbach's } \\
\boldsymbol{\alpha} \\
\end{array}$ & AVE & $\begin{array}{l}\text { Composite } \\
\text { Reliability }\end{array}$ \\
\hline \multirow{6}{*}{ Attitude } & ATT1 & 0.769 & \multirow{6}{*}{0.829} & \multirow{6}{*}{0.581} & \multirow{6}{*}{0.890} \\
\hline & ATT2 & 0.701 & & & \\
\hline & ATT3 & 0.789 & & & \\
\hline & ATT4 & 0.698 & & & \\
\hline & ATT5 & 0.739 & & & \\
\hline & ATT6 & 0.779 & & & \\
\hline \multirow{4}{*}{ Subjective norm } & SBN1 & 0.749 & \multirow{4}{*}{0.761} & \multirow{4}{*}{0.656} & \multirow{4}{*}{0.883} \\
\hline & SBN2 & 0.641 & & & \\
\hline & SBN3 & 0.652 & & & \\
\hline & SBN4 & 0.761 & & & \\
\hline \multirow{2}{*}{ Perceived behavioral control } & PBC1 & 0.743 & \multirow{2}{*}{0.689} & \multirow{2}{*}{0.635} & \multirow{2}{*}{0.694} \\
\hline & PBC2 & 0.656 & & & \\
\hline \multirow{6}{*}{ Environmental concern } & EC1 & 0.718 & \multirow{6}{*}{0.787} & \multirow{6}{*}{0.504} & \multirow{6}{*}{0.853} \\
\hline & EC2 & 0.701 & & & \\
\hline & EC3 & 0.583 & & & \\
\hline & EC4 & 0.677 & & & \\
\hline & EC5 & 0.523 & & & \\
\hline & EC6 & 0.666 & & & \\
\hline \multirow{4}{*}{ Purchase intention } & PI1 & 0.606 & \multirow{4}{*}{0.737} & \multirow{4}{*}{0.720} & \multirow{4}{*}{0.911} \\
\hline & PI2 & 0.597 & & & \\
\hline & PI3 & 0.666 & & & \\
\hline & PI4 & 0.557 & & & \\
\hline
\end{tabular}

Tab. 3 - Expected discriminant validity. Source: own research

\begin{tabular}{|l|c|c|c|c|c|}
\hline \multicolumn{1}{|c|}{ Construct } & Attitude & $\begin{array}{c}\text { Environmental } \\
\text { control }\end{array}$ & $\begin{array}{c}\text { Perceived } \\
\text { behavioral control }\end{array}$ & $\begin{array}{c}\text { Purchase } \\
\text { intention }\end{array}$ & $\begin{array}{c}\text { Subjective } \\
\text { norm }\end{array}$ \\
\hline Attitude & $\mathbf{0 . 7 6 2}$ & & & & \\
\hline Environmental control & 0.375 & $\mathbf{0 . 7 1 0}$ & & & \\
\hline Perceived behavioral control & 0.567 & 0.203 & $\mathbf{0 . 7 5 1}$ & & \\
\hline Purchase intention & 0.655 & 0.372 & 0.509 & $\mathbf{0 . 8 4 9}$ & \\
\hline Subjective norm & 0.613 & 0.175 & 0.575 & 0.630 & $\mathbf{0 . 8 1 0}$ \\
\hline
\end{tabular}


Tab. 4 - Evaluation of hypotheses testing. Source: own research

\begin{tabular}{|c|c|c|c|c|}
\hline Hypotheses & Path & $t$-value & $p$-value & $\begin{array}{c}\text { Hypotheses } \\
\text { supported }\end{array}$ \\
\hline H1 & ATT $\rightarrow$ PI (+) & 2.794 & 0.005 & Yes \\
\hline H2 & SBN $\rightarrow$ PI (+) & 2.336 & 0.020 & Yes \\
\hline H3 & PBC $\rightarrow$ PI (+) & 2.872 & 0.004 & Yes \\
\hline H4 & ECxATT $\rightarrow$ PI (+) & 2.454 & 0.005 & Yes \\
\hline
\end{tabular}

Based on the analysis in Table 5, with p-value $<0,05$, the analysis confirms the Theory of Planned Behaviour which illustrates the hypotheses supports of attitude, subjective norms and perceived behaviour control to purchase intention, supporting $\mathrm{H} 1, \mathrm{H} 2, \mathrm{H} 3$. Moreover, according to Table 5, the interaction of environmental concern and attitude ( $\mathrm{p}$-value $<0.05$ ) positively and significantly influences purchase intention, supporting $\mathrm{H} 4$. With the moderation effect of environmental concern to the relationship of attitude and purchase intention, the effect show that when environmental concern increase the relationship between attitude and purchase intention increase.

\section{DISCUSSION AND CONCLUSIONS}

Our findings are highlighted and discussed with respect to the two research questions as follows. Regarding the first research question, the study illustrates the moderation effect of environmental concern to the relationship of attitude and purchase intention. This indicate that extended TPB has higher utility than TPB and TRA to predict organic food purchase intention in Vietnam. Moreover, according to second research question, this study confirmed relationships in TPB as a research model useful for explaining consumers' organic food purchase intention.

The study's main contribution is that the interactive effect of Environmental concern (EC) and attitude is significant and positive to purchase intention. When consumers' attitude is positive and they display higher concern for environment, they will more likely make efforts to reduce their environmental impact and have more intention to buy organic food. In the practical fields, companies understand the importance of environmental concern of their customers. Companies which have more marketing campaigns toward to environmental concern will increase purchase intention of customers. It leads to increase in revenue as well as environment protection.

\section{Limitation and future research}

The limitations of the study can be classified into two points. First, this study considers organic food only and this research model can be tested to another product in green area. Future research should test this proposed model in various green product settings, including recyclable products, green certified products, laundry and hotels. Second, more relevant variables like environmental knowledge, environmental awareness can be added to test model's sufficiency in predicting organic food purchase intentions.

\section{References}

Abrahamse, W., \& Steg, L. (2009). How do socio-demographic and psychological factors relate to households' direct and indirect energy use and savings? Journal of Economic Psychology, 30(5), 711-720. doi: 10.1016/j.joep.2009.05.006

Ajzen, I. (1991). The theory of planned behaviour. Organizational Behaviour and Human Decision Processes, 50(2), 179-211. doi: 10.1016/0749-5978(91)90020-T 
Ajzen, I. (2002). Perceived behavioural control, self-efficacy, locus of control, and the theory of planned behaviour. Journal of Applied Social Psychology, 32(4), 665-683. doi: 10.1111/j.1559-1816.2002.tb00236.x

Al, A., Rosli, M., Ra, M., \& Mohiuddin, M. (2018). Intention and behaviour towards green consumption among low-income households. Journal of Environmental Management, 227, 73-86. doi: 10.1016/j.jenvman.2018.08.061

AlYahmady, H. H., \& Abri, S. S. A. (2013). Using Nvivo for Data Analysis in Qualitative Research. International Interdisciplinary Journal of Education, 2(2), 181-186. doi: $10.12816 / 0002914$

Aman, A., Harun, A., \& Hussein, Z. (2012). The influence of environmental knowledge and concern on green purchase intention the role of attitude as a mediating variable. British Journal of Arts and Social Sciences, 7(2), 145-167. Retrieved from https://core.ac.uk/download/pdf/154907984.pdf

Arvola, A., Vassallo, M., Dean, M., Lampila, P., Saba, A., Lähteenmäki, L., \& Shepherd, R. (2008). Predicting intentions to purchase organic food: The role of affective and moral attitudes in the Theory of Planned Behaviour. Appetite, 50(2-3), 443-454. doi: 10.1016/j.appet.2007.09.010

Aryal, K. P., Chaudhary, P., Pandit, S., \& Sharma, G. (2009). Consumers' Willingness to Pay for Organic Products: A Case from Kathmandu Valley. Journal of Agriculture and Environment, 10, 15. doi: 10.3126/aej.v10i0.2126

Bonti-ankomah, S., \& Yiridoe, E. K. (2006). Organic and Conventional Food: A Literature Review of the Economics of Consumer Perceptions and Preferences. Organic and Conventional Food: A Literature Review of the Economics of Consumer Perceptions and Preferences. Retrieved from citeseerx.ist.psu.edu/viewdoc/download?doi=10.1.1.459.7393\&rep=rep1\&type=pdf

Bryman, A., \& Bell, E. (2011). Business research methods). New York: Oxford University Press.

Chekima, B., Chekima, K., \& Chekima, K. (2019). Understanding factors underlying actual consumption of organic food: The moderating effect of future orientation. Food Quality and Preference, 74, 49-58. doi: 10.1016/j.foodqual.2018.12.010

Chen, A., \& Peng, N. (2012). Green hotel knowledge and tourists' staying behaviour. Annals of Tourism Research, 39(4), 2211-2216. doi: 10.1016/j.annals.2012.07.003

Chen, M. F. (2007). Consumer attitudes and purchase intentions in relation to organic food in Taiwan: Moderating effects of food-related personality traits. Food Quality and Preference, 18(7), 1008-1021. doi: 10.1016/j.foodqual.2007.04.004

Clark, C. F., Kotchen, M. J., \& Moore, M. R. (2003). Internal and external influences on proenvironmental behaviour: Participation in a green electricity program. Journal of Environmental Psychology, 23(3), 237-246. doi: 10.1016/S0272-4944(02)00105-6

Creswell, J. W. (2014). Research design: qualitative, quantitative, and mixed methods approaches. Thousand Oaks: SAGE Publications.

Diamantopoulos, A., Schlegelmilch, B. B., Sinkovics, R. R., \& Bohlen, G. M. (2003). Can socio-demographics still play a role in profiling green consumers? A review of the evidence and an empirical investigation. Journal of Business Research, 56(6), 465-480. doi: 10.1016/S0148-2963(01)00241-7 
Fishbein, M., \& Ajzen, I. (1977). Belief, Attitude, Intention, and Behaviour: An Introduction to Theory and Research. Journal of Business Venturing, 5, 177-189. doi: $10.2307 / 2065853$

Fornell, C., \& Larcker, D. F. (1981). Evaluating Structural Equation Models with Unobservable Variables and Measurement Error. Journal of Marketing Research, 18(1), 39. doi: $10.2307 / 3151312$

Hair, J., Black, W. C., Babin, B. J., \& Anderson, R. E. (2013). Multivariate Data Analysis: Pearson New International Edition. London: Pearson.

Han, H., Hsu, L. T., \& Lee, J. S. (2009). Empirical investigation of the roles of attitudes toward green behaviours, overall image, gender, and age in hotel customers' eco-friendly decision-making process. International Journal of Hospitality Management, 28(4), 519528. doi: 10.1016/j.ijhm.2009.02.004

Han, H., Hsu, L. T., \& Sheu, C. (2010). Application of the Theory of Planned Behaviour to green hotel choice: Testing the effect of environmental friendly activities. Tourism Management, 31(3), 325-334. doi: 10.1016/j.tourman.2009.03.013

Han, H., \& Kim, Y. (2010). An investigation of green hotel customers' decision formation: Developing an extended model of the theory of planned behaviour. International Journal of Hospitality Management, 29(4), 659-668. doi: 10.1016/j.ijhm.2010.01.001

Hartmann, P., \& Apaolaza-Ibáñez, V. (2012). Consumer attitude and purchase intention toward green energy brands: The roles of psychological benefits and environmental concern. Journal of Business Research, 65(9), 1254-1263. doi: 10.1016/j.jbusres.2011.11.001

Hayes, A. F., \& Rockwood, N. J. (2017). Regression-based statistical mediation and moderation analysis in clinical research: Observations, recommendations, and implementation. Behaviour Research and Therapy, 98, 39-57. doi: 10.1016/j.brat.2016.11.001

Hedlund, T. (2011). The impact of values, environmental concern, and willingness to accept economic sacrifices to protect the environment on tourists' intentions to buy ecologically sustainable tourism alternatives. Tourism and Hospitality Research, 11(4), 278-288. doi: 10.1177/1467358411423330

Hu, H. H., Parsa, H. G., \& Self, J. (2010). The dynamics of green restaurant patronage. Cornell Hospitality Quarterly, 51(3), 344-362. doi: 10.1177/1938965510370564

Kalafatis, S. P., Pollard, M., East, R., \& Tsogas, M. H. (1999). Green marketing and Ajzen's theory of planned behaviour: A cross-market examination. Journal of Consumer Marketing, 16(5), 441-460. doi: 10.1108/07363769910289550

Kilbourne, W., \& Pickett, G. (2008). How materialism affects environmental beliefs, concern, and environmentally responsible behaviour. Journal of Business Research, 61(9), 885893. doi: 10.1016/j.jbusres.2007.09.016

Kim, E., Ham, S., Yang, I. S., \& Choi, J. G. (2013). The roles of attitude, subjective norm, and perceived behavioural control in the formation of consumers' behavioural intentions to read menu labels in the restaurant industry. International Journal of Hospitality Management, 35, 203-213. doi: 10.1016/j.ijhm.2013.06.008

Krystallis, A., \& Chryssohoidis, G. (2005). Consumers' willingness to pay for organic food. British Food Journal, 107(5), 320-343. doi: 10.1108/00070700510596901 
Laroche, M., Bergeron, J., \& Barbaro-Forleo, G. (2001). Targeting consumers who are willing to pay more for environmentally friendly products. Journal of Consumer Marketing, 18(6), 503-520. doi: 10.1108/EUM0000000006155

Leelapattana, W., Hsu, S. Y., Thongma, W., Chen, C., \& Chiang, F. M. (2019). Understanding the impact of environmental education on tourists' future Visit Intentions to Leisure Farms in Mountain Regions. Sustainability, 11(6), 1567. doi: 10.3390/su11061567

Li, G., Li, W., Jin, Z., \& Wang, Z. (2019). Influence of environmental concern and knowledge on households' willingness to purchase energy-efficient appliances: A case study in Shanxi, China. Sustainability, 11(4), 1-18. doi: 10.3390/su11041073

Maichum, K., Parichatnon, S., \& Peng, K. C. (2016). Application of the extended theory of planned behaviour model to investigate purchase intention of green products among Thai consumers. Sustainability, 8(10), 1-20. doi: 10.3390/su8101077

Michaelidou, N., \& Hassan, L. M. (2008). The role of health consciousness, food safety concern and ethical identity on attitudes and intentions towards organic food. International Journal of Consumer Studies, 32(2), 163-170. doi: 10.1111/j.1470-6431.2007.00619.x

Mostafa, M. M. (2007). A Hierarchical Analysis of the Green Consciousness of the Egyptian Consumer. Psychology \& Marketing, 24(05), 445-473. doi: 10.1002/mar

Mostafa, M. M. (2009). Shades of green: A psychographic segmentation of the green consumer in Kuwait using self-organizing maps. Expert Systems with Applications, 36(8), 1103011038. doi: 10.1016/j.eswa.2009.02.088

Nosi, C., Pucci, T., Silvestri, C., \& Aquilani, B. (2017). Does value co-creation really matter? An investigation of Italian millennials intention to buy electric cars. Sustainability, 9(12), 1-21. doi: 10.3390/su9122159

Paul, J., Modi, A., \& Patel, J. (2016). Predicting green product consumption using theory of planned behaviour and reasoned action. Journal of Retailing and Consumer Services, 29, 123-134. doi: 10.1016/j.jretconser.2015.11.006

Peighambari, K., Sattari, S., Kordestani, A., \& Oghazi, P. (2016). Consumer Behaviour Research: A Synthesis of the Recent Literature. SAGE Open, 6(2). doi: $10.1177 / 2158244016645638$

Pham, N. T., Tučková, Z., \& Chiappetta Jabbour, C. J. (2019). Greening the hospitality industry: How do green human resource management practices influence organizational citizenship behaviour in hotels? A mixed-methods study. Tourism Management, 72(August), 386-399. doi: 10.1016/j.tourman.2018.12.008

Pham, T. H., Nguyen, T. N., Phan, T. T. H., \& Nguyen, N. T. (2018). Evaluating the purchase behaviour of organic food by young consumers in an emerging market economy. Journal of Strategic Marketing, 4488, 1-17. doi: 10.1080/0965254X.2018.1447984

Pomsanam, P., Napompech, K., \& Suwanmaneepong, S. (2014). An exploratory study on the organic food purchase intention among Thai-Cambodian cross-border consumers. Asian Journal of Applied Sciences. doi: 10.3923/ajaps.2014.294.305

Ragavan, \& Mageh. (2012). A Study on Consumers' Purchase Intentions Towards Organic Products. Paripex - Indian Journal of Research, 2(1), 111-114. doi: 10.15373/22501991/jan2013/41 
Sang, Y. N., \& Bekhet, H. A. (2015). Modelling electric vehicle usage intentions: An empirical study in Malaysia. Journal of Cleaner Production, 92, 75-83. doi: 10.1016/j.jclepro.2014.12.045

Saunders, M. N. K., Lewis, P., \& Thornhill, A. (2009). Research methods for business students. Harlow: Pearson.

Shaharudin, M. R., Pani, J. J., Mansor, W. S., \& Elias, J. S. (2010). Factors Affecting Purchase Intention of Organic Food in Malaysia's Kedah State. Cross-Cultural Communication, 6(2), 105-116. Retrieved from https://www.researchgate.net/publication/44926510_Factors_Affecting_Purchase_Inte ntion_of_Organic_Food_in_Malaysia's_Kedah_State

Shen, L., Si, H., Yu, L., \& Si, H. (2019). Factors influencing young people's intention toward municipal solid waste sorting. International Journal of Environmental Research and Public Health, 16(10). doi: 10.3390/ijerph16101708

Singh, A., \& Verma, P. (2018). Factors influencing Indian consumers' actual buying behaviour towards organic food products. Journal of Cleaner Production, 167, 473-483. doi: 10.1016/j.jclepro.2017.08.106

Tsakiridou, E., Boutsouki, C., Zotos, Y., \& Mattas, K. (2008). Attitudes and behaviour towards organic products: an exploratory study. International Journal of Retail \& Distribution Management, 36(2), 158-175. doi: 10.1108/09590550810853093

Verbeke, W., Sioen, I., Brunsø, K., Henauw, S., \& Camp, J. (2007). Consumer perception versus scientific evidence of farmed and wild fish: Exploratory insights from Belgium. Aquaculture International, 15(2), 121-136. doi: 10.1007/s10499-007-9072-7

Walker, A. E., Grimshaw, J. M., \& Armstrong, E. M. (2001). Salient beliefs and intentions to prescribe antibiotics for patients with a sore throat. British Journal of Health Psychology, 6(4), 347-360. doi: 10.1348/135910701169250

Wang, C., Zhang, J., Yu, P., \& Hu, H. (2018). The theory of planned behaviour as a model for understanding tourists' responsible environmental behaviours: The moderating role of environmental interpretations. Journal of Cleaner Production, 194, 425-434. doi: 10.1016/J.JCLEPRO.2018.05.171

Whitmarsh, L., \& O’Neill, S. (2010). Green identity, green living? The role of proenvironmental self-identity in determining consistency across diverse proenvironmental behaviours. Journal of Environmental Psychology, 30(3), 305-314. doi: 10.1016/j.jenvp.2010.01.003

Yadav, R., \& Pathak, G. S. (2016). Young consumers' intention towards buying green products in a developing nation: Extending the theory of planned behaviour. Journal of Cleaner Production, 135, 732-739. doi: 10.1016/j.jclepro.2016.06.120

Yazdanpanah, M., \& Forouzani, M. (2015). Application of the Theory of Planned Behaviour to predict Iranian students' intention to purchase organic food. Journal of Cleaner Production, 107, 342-352. doi: 10.1016/j.jclepro.2015.02.071

Yiridoe, E. K., Tsakiridou, E., Boutsouki, C., Zotos, Y., Mattas, K., Shaharudin, M. R., \& Sharma, G. (2014). Attitudes and behaviour towards organic products: an exploratory study. International Journal of Business Excellence, 10(2), 320-343. doi: 10.3126/aej.v10i0.2126 
Zemore, S. E., \& Ajzen, I. (2014). Predicting substance abuse treatment completion using a new scale based on the theory of planned behaviour. Journal of Substance Abuse Treatment, 46(2), 174-182. doi: 10.1016/j.jsat.2013.06.011

Zhang, B., Fu, Z., Huang, J., Wang, J., \& Xu, S. (2018). Consumers' perceptions, purchase intention, and willingness to pay a premium price for safe vegetables: A case study of Beijing, China Conventional vegetable. Journal of Cleaner Production, 197, 14981507. doi: 10.1016/j.jclepro.2018.06.273

\section{Contact information}

\section{Hung Cuong Hoang}

Tomas Bata University in Zlín, Faculty of Management and Economics

Mostní 5139, 76001, Zlín, Czech Republic

E-mail: hoang@utb.cz

ORCID: 0000-0003-0732-8319

\section{Thi Que Huong Hoang}

University of Economics and Law, Faculty of International Economic Relations

Quarter 3, Linh Xuan Ward, Thu Duc District, Ho Chi Minh City

E-mail: huonghtq@uel.edu.vn

ORCID: 0000-0002-0111-0004

doc. Ing. Miloslava Chovancová, CSc.

Tomas Bata University in Zlín, Faculty of Management and Economics

Mostní 5139, 76001, Zlín, Czech Republic

E-mail: chovancova@utb.cz

ORCID: 0000-0002-9244-9563

\section{Abdul Bashiru Jibril}

Tomas Bata University in Zlín, Faculty of Management and Economics Mostní 5139, 76001, Zlín, Czech Republic

E-mail: jibril@utb.cz

ORCID: 0000-0003-4554-0150

doi: 10.7441/dokbat.2019.035 